Jarostaw Horowski*

Toruń

\title{
Pedagogiczne pytania o przebaczenie
}

W 2013 roku na Wydziale Nauk Pedagogicznych Uniwersytetu Mikołaja Kopernika w Toruniu odbyło się spotkanie studentów pedagogiki z dwiema osobami osadzonymi w Zakładzie Karnym we Włocławku. Byli to skazani odbywający długie wyroki - po 25 lat pozbawienia wolności. Osadzeni otrzymali jednodniowe przepustki i przybyli na uniwersytet sami, bez funkcjonariuszy, co stwarzało okazję do w miarę szczerej z nimi rozmowy. Można było spodziewać się, że studenci, którzy szczelnie wypełnili aulę, wykorzystają tę okazję do zdobycia informacji o życiu za murami więzienia, szukając jego obrazu z perspektywy osób skazanych. Tymczasem rozmowa po kilkunastu minutach niespodziewanie, ale szczęśliwie, odbiegła od tematu. Odpowiadając na pytanie o trudności związane z przystosowaniem do funkcjonowania w warunkach izolacji, jeden z gości przyznał, że jest to bardzo długi proces, trwający niejednokrotnie latami, a jego przełomowym momentem jest wybaczenie sobie. Od tego rozpoczęło się opowiadanie osobistej historii, w której gniew i pragnienie zemsty wywołały wiele nieszczęść. Doprowadziły do pozbawienia życia innego człowieka i zniszczenia życia jego bliskich, a równocześnie do odebrania sobie, własnej żonie oraz rodzicom szansy na szczęśliwe życie. Osadzony stwierdził, że początek próby odbudowy tego życia i chociaż częściowego naprawienia zła, które popełnił, wiąże się z wybaczeniem sobie. W tej atmosferze drugi ze skazanych

* Dr hab. Jarosław Horowski jest adiunktem w Katedrze Teorii Wychowania na Wydziale Nauk Pedagogicznych Uniwersytetu Mikołaja Kopernika w Toruniu. Adres: Wydział Nauk Pedagogicznych UMK, ul. Lwowska 1,87-100 Toruń; e-mail: jarohor@umk.pl. 
opowiedział historię mediacji, o którą po 10 latach od zapadnięcia wyroku poprosiła żona człowieka, którego - jako siedemnastolatek - zabił. Przygotowując się do niej, spodziewał się, że rozmowa będzie dotyczyła roszczeń, ewentualnego odszkodowania, tymczasem kobieta ta przyjechała na spotkanie, aby powiedzieć zabójcy swojego męża o wybaczeniu - stwierdziła, że postrzega je jako jedyny sposób na uratowanie resztek swojego życia, które nie może dłużej toczyć się w klimacie żalu, gniewu, pragnienia zemsty.

Wnioskiem ze spotkania studentów z osadzonymi mogłoby być stwierdzenie, że zarówno krzywda, jak i odpowiedź na nią - czy to poprzez przebaczenie, czy przez jego odmowę - stanowią nieodłączny element ludzkiego życia, wpisują się w rozwój człowieka i jako takie powinny stać się przedmiotem refleksji pedagogicznej ${ }^{1}$. Kwestii zależności między wskazanymi płaszczyznami nie da się jednak rozstrzygnąć jednoznacznymi stwierdzeniami. Mimo że przebaczenie postrzegane jest jako akt pozytywny, jako działanie zmierzające do przynajmniej częściowej neutralizacji przez pokrzywdzonego negatywnych konsekwencji czynu drugiego człowieka, nie sposób nie zauważyć, że przebaczenie, do którego pokrzywdzony wewnętrznie nie dojrzał, może niszczyć jego samego, a akt przebaczenia sprawcy zła, który nie rozumie tego, co czyni, może utwierdzać go w słuszności złego postępowania. W tym kontekście, myśląc o roli przebaczenia w wychowaniu, a w konsekwencji także o wychowaniu do przebaczenia, należy zadać pytania o istotę przebaczenia, o jego moralną wartość, a zwłaszcza stosunek do sprawiedliwości, o jego uwarunkowania i przebieg, wreszcie o jego wymiar religijny. Niniejszy tekst ma charakter wprowadzający do tematu - jego celem jest nakreślenie problemów, postawienie pytań, a nie ich rozwiązywanie. Spróbujmy zatem zastanowić się, na jakie pytania należy uzyskać odpowiedzi, zanim kwestia przebaczenia zostanie włączona do refleksji pedagogicznej i praktyki wychowawczej.

${ }^{1}$ Niestety pedagodzy rzadko podejmują pytanie o wychowanie do przebaczenia, choć zdarzają się prace na ten temat. Zob.: Katarzyna Wrońska, „Przebaczenie jako problem wychowania”, w: Pedagogika kultury - wychowanie do wyboru wartości, red. Bogusław Żurakowski (Kraków: Oficyna wydawnicza „Impuls”, 2003), 57-78; Aldona Król, „Wychowanie do przebaczenia”, w: Wychowanie chrześcijańskie. Między tradycja a wspótczesnościa, red. Alina Rynio (Lublin: Wydawnictwo KUL, 2007), 432-442; Katarzyna Szymala, „Przebaczenie jako działanie. O znaczeniu tego, co nieprzewidywalne dla edukacji”, Parezja 1 (2015): 103-116. 


\section{Na czym polega przebaczenie?}

Historia przebaczenia jako zjawiska jest z pewnością tak długa, jak długa jest historia człowieka². Biorąc bowiem pod uwagę przygodność człowieka, a w konsekwencji niedoskonałość jego władz poznawczych i słabość władz pożądawczych, należy przypuszczać, że w relacjach międzyludzkich zawsze pojawiało się zło, czy to na skutek błędów poznawczych, czy - co gorsza - w konsekwencji złej woli (wad charakteru) sprawcy czynu. Zawsze też człowiek doświadczający owego zła musiał jakoś odnieść się do niego, a przebaczenie stanowiło jedną $\mathrm{z}$ alternatywnych odpowiedzi na doznaną krzywdę ${ }^{3}$. Mimo że krzywda i przebaczenie stanowią nieodłączny element ludzkiego życia, zdefiniowanie przebaczenia nastręcza trudności.

W literaturze przedmiotu dyskusje nad istotą przebaczenia odnoszą się w punkcie wyjścia do definicji zaproponowanej przez bpa Josepha Butlera, angielskiego filozofa i teologa, według której przebaczenie jest wyrzeczeniem się resentymentu (żalu, urazy), przy czym resentyment rozumiany jest jako negatywne uczucia (złości, nienawiści) w stosunku do osoby, która wyrządziła moralną krzywdę. $\mathrm{Z}$ ujęciem tym podejmowana jest jednak dyskusja. Nie stwierdza się, że jest ono błędne, ale wskazuje się na fakt, że nie obejmuje całego spektrum rzeczywistości określanej mianem przebaczenia. Wątpliwości co do trafności sformułowania zaproponowanego przez Butlera wyraża na przykład Norvin Richards. Wskazuje, że tak zdefiniowanego pojęcia nie można odnieść do sytuacji, w której czyjeś zdradliwe zachowanie nie prowadzi u skrzywdzonego do uczucia urazy, żalu, ale do pogardy dla sprawcy zła. Inny przykład związany jest z uczuciem smutku czy rozczarowania, które pojawiają się w konsekwencji złego potraktowania, a nie są połączone z żalem czy pogardą, ponieważ krzywdziciel jest kimś bliskim, kochanym, na przykład dzieckiem. Zdaniem Richardsa definicja przebacze-

2 Choć Hannah Arendt twierdzi, że „Odkrywcą roli przebaczenia w dziedzinie spraw ludzkich był Jezus z Nazaretu. (...) dokonał tego odkrycia w kontekście religijnym i wyraził je w języku religijnym" (Hannah Arendt, Kondycja ludzka, thum. Anna Łagodzka [Warszawa: Wydawnictwo Aletheia, 2010], 271).

3 Paul M. Hughes, „Forgiveness”, w: The Stanford Encyclopedia of Philosophy, red. Edward N. Zalta (Spring 2015 Edition), http://plato.stanford.edu/archives/spr2015/entries/forgiveness/ (dostęp: 19.05.2016).

4 Jeffrie G. Murphy, „Forgiveness and mercy”, w: Routledge Encyclopedia of Philosophy, t. 3, red. Edward Craig (London-New York: Routledge, 1998), 698; Jeffrie G. Murphy, „Forgiveness and Resentment”, Midwest Studies in Philosophy 7, 1 (1982): 504. 
nia powinna być na tyle szeroka, aby objąć tym pojęciem także wycofanie wskazanych przez niego innych negatywnych uczuć w stosunku do osoby, ze strony której doświadczyło się zła ${ }^{5}$. Podobne stanowisko zajmuje Macalester Bell, która opowiada się za szerszym niż zaproponowane przez Butlera ujęciem ${ }^{6}$.

Przyglądając się czy to sformułowanemu przez Butlera wąskiemu ujęciu, czy też definicjom poszerzającym gamę uczuć przezwyciężanych przez przebaczenie, należy ponadto zwrócić uwagę, że wskazują one na istotę aktu przebaczenia, ale nie odnoszą się do zewnętrznych przejawów przebaczenia. Z tego względu mogą zostać zastosowane w dwóch różnych sytuacjach. Po pierwsze, gdy osoba pokrzywdzona przekazuje swojemu krzywdzicielowi informację o przebaczeniu (abstrahuję od kwestii, czy owa informacja służy pojednaniu między stronami, czy nie ma na celu odbudowania relacji, które albo nigdy nie istniały, ponieważ sprawca i pokrzywdzony byli sobie obcy, albo nie mogą zostać odbudowane, ponieważ pokrzywdzony mimo przebaczenia - nadal czuje zagrożenie ze strony sprawcy). Po drugie, gdy owa informacja nie jest przekazywana. $Z$ jednej strony wydaje się, że przebaczenie może się dokonać bez zakomunikowania tej decyzji sprawcy zła. $\mathrm{Z}$ drugiej natomiast strony ów akt może jawić się jako niepełny bez wspomnianej komunikacji, a nawet niezrealizowany, ponieważ pozostawia sprawcę żywiącego nadzieję na przebaczenie w przeświadczeniu jego nieotrzymania.

Z tych rozważań wynikają pierwsze pytania, na które należy udzielić odpowiedzi, identyfikując zależności między przebaczeniem a edukacją:

- jaka jest istota przebaczenia (rezygnacji z których uczuć ono dotyczy)?

- jaką rolę odgrywa $\mathrm{w}$ akcie przebaczenia informacja przekazana sprawcy zła przez osobę pokrzywdzoną o podjęciu decyzji dotyczącej przebaczenia?

Postawione tutaj pytania odnoszą się do definicji zjawiska i - choć ważne - nie wskazują na żadne kontrowersje z nim związane. $\mathrm{Z}$ zupełnie inną sytuacją mamy do czynienia, gdy podejmujemy kwestię moralnej wartości przebaczenia.

${ }^{5}$ Norvin Richards, „Forgiveness”, Ethics 99, 1 (1988): 77-78.

${ }^{6}$ Macalester Bell, „Forgiving Someone for Who They Are (and Not Just What They've Done)", Philosophy and Phenomenological Research 3 (2008): 626-631. 


\section{Jaką wartość moralną posiada przebaczenie?}

Przebaczenie jest wartościowane, szczególnie w kulturze Zachodu, jako działanie dobre. Takie podejście do przebaczenia budowane jest $\mathrm{z}$ jednej strony na fundamencie pozytywnych doświadczeń związanych z przebaczeniem, w których decyzja osoby skrzywdzonej o przebaczeniu pozwoliła odnowić zniszczone relacje i w ten sposób - przynajmniej częściowo - zniwelować skutki nieodwracalnego zła, a z drugiej wzmacniane jest przez chrześcijaństwo i przekazywane przez tę religię wezwanie do przebaczenia ,aż siedemdziesiąt siedem razy” (Mt 18, 22). Tymczasem, żeby mówić o moralnej wartości jakiegoś aktu, należy przyjrzeć się jego konsekwencjom w odniesieniu zarówno do osoby podejmującej o nim decyzję, jak i osób doświadczających jego skutków. Dobra decyzja to decyzja roztropna, czyli taka, która bierze pod uwagę wszystkie skutki czynu, a konkretniej dobro wszystkich osób, doświadczających konsekwencji czynu. Spróbujmy przyjrzeć się zatem konsekwencjom przebaczenia.

Pierwszą z osób, które doświadczają skutków przebaczenia, jest sama osoba pokrzywdzona. Owe skutki mogą być zarówno pozytywne, jak i negatywne. Do tych pierwszych należy niewątpliwie zaliczyć uporanie się z uczuciami złości, nienawiści, żalu, smutku, które - mimo że ich przedmiotem jest inny człowiek - osadzone są w osobie pokrzywdzonej i to ją dotykają (a nawet niszczą) w pierwszej kolejności. Są to uczucia, które odbierają radość życia i prowadzą do zniechęcenia ${ }^{7}$. Warto w tym kontekście zwrócić uwagę na analizy, które przeprowadził Max Scheler w odniesieniu do resentymentu, wskazując, w jaki sposób może się on rozwinąc i do jakich stanów w ludzkim życiu doprowadzić ${ }^{8}$. Zło czynu może obejmować zatem nie tylko bezpośrednie jego konsekwencje, ale może także ujawniać się w dłuższej perspektywie czasowej. Przebaczenie staje się w tej sytuacji sposobem na uniknięcie przez samego pokrzywdzonego negatywnych konsekwencji czynu, który naruszył jego dobro?.

7 Józef Augustyn, Ból krzywdy, radość przebaczenia (Kraków: Wydawnictwo M, 1998), 95-102; Ernie Larsen, Od gniewu do przebaczenia. Jak przezwyciężý toksyczne emocje, by żyć w zgodzie ze sobq, tłum. Ewa Zaremba (Gdańsk: GWP, 2000), 91-92. O konsekwencjach zniechęcenia duchowego i gniewu: Mirosław Mróz, Tajemnica ludzkiej nieprawości. Aktualność nauki św. Tomasz z Akwinu o złu moralnym $i$ wadach głównych (Toruń: Wydawnictwo Naukowe UMK, 2010), 383-451.

${ }^{8}$ Max Scheler, Resentyment a moralność, tłum. Jan Garewicz (Warszawa: Czytelnik, 1997).

${ }^{9} \mathrm{Na}$ ten wymiar przebaczenia zwracają uwagę przede wszystkim terapeuci. Anselm 
Jednak wycofanie negatywnych uczuć skierowanych ku osobie, ze strony której doświadczyło się zła, może w niektórych przypadkach utrwalać pozostawanie przez osobę skrzywdzoną w relacji, która jest dla niej niszcząca. Wspomniany już Norvin Richards podaje przykład przebaczenia motywowanego podporządkowaniem normom religijnym, które utwierdza osobę krzywdzoną w destrukcyjnej dla niej relacji i w dalszej konsekwencji wywołuje żal, smutek w odniesieniu do niej samej ${ }^{10}$. Dyskutując z nim, można by powiedzieć, że czymś innym jest przebaczenie, a czymś innym zerwanie destrukcyjnej relacji, na przykład separacja z mężem alkoholikiem, borykającym się z problemem, wobec którego żona jest bezsilna. Można przecież przebaczyć (nie mieć do kogoś żalu), a równocześnie zadbać o własne dobro oraz dobro innych osób, za które jest się odpowiedzialnym (przede wszystkim dzieci), urywając będącą kontekstem krzywd relację. W praktyce jednak te dwa działania nie dają się tak łatwo rozgraniczyć, ponieważ przebaczenie motywowane jest często pragnieniem odbudowania relacji.

Przebaczenie wywołuje także konsekwencje w życiu osoby, która go doświadcza. Również w tym przypadku jego wartość nie jest jednoznaczna. Jeżeli sprawca rozumie zło własnego czynu, pragnie je naprawić i prosi o wybaczenie ${ }^{11}$, a przy tym zmienił swoje postępowanie, spełnienie tej prośby może ułatwić naprawienie zła i utwierdzić dobro. Jeżeli jednak nie dostrzega zła, które wywołał, i nie przeprasza za nie, wybaczanie mu może utwierdzić go w przekonaniu o słuszności jego postępowania i w ten spo-

Grün w jednej ze swoich książek pisze: „Jeśli nie przebaczam, ten drugi ciagle jeszcze ma nade mną władzę, oddziałuje na moje myśli i uczucia. Przebaczenie wyzwala mnie spod jego władzy. Przestaje on być moim przeciwnikiem, jest zranionym i zaślepionym człowiekiem, który nie potrafi zachowywać się inaczej" (Anselm Grün, Przebacz samemu sobie. Pojednanie - przebaczenie, tłum. Juliusz Zychowicz [Kraków: Wydawnictwo WAM, 2001], 14). Znaczenie przebaczenia dla psychoterapii znalazło szerokie opracowanie w literaturze przedmiotu. Zob. np.: David Augsburger, Sztuka przebaczania, thum. Andrzej Czarnocki (Warszawa: Świat Książki, 1996), 45-58; William West, ,Issues relating to the use of forgiveness in counselling and psychotherapy”, British Journal of Guidance \& Counselling 4 (2001): 415-423; Mark S. Rye, Kenneth I. Pargament, „Forgiveness and Romantic Relationship in College. Can It Heal the Wounded Heart?", Journal of Clinical Psychology 4 (2002): 419-441; Alex H. S. Harris, Frederic Luskin, Sonya B. Norman, Sam Standard, Jennifer Bruning, Stephanie Evans, and Carl E. Thoresen, „Effects of a Group Forgiveness Intervention on Forgiveness, Perceived Stress, and Trait-Anger", Journal of Clinical Psychology 6 (2006): 715-733.

${ }^{10}$ Richards, „Forgiveness”, 78; por. West, „Issues”, 421.

${ }^{11}$ Sprawca zła może je dostrzegać i poszukiwać przebaczenia: Rodney L. Bassett, Kelly M. Bassett, Matthew W. Lloyd, Jason L. Johnson, „Seeking Forgiveness: Considering the Role of Moral Emotions", Journal of Psychology and Theology 34, 2 (2006): 111-124. 
sób utrwalać wady jego charakteru ${ }^{12}$. Przebaczenie można by, oczywiście, odróżnić od zewnętrznego aktu zakomunikowania o nim. Można przecież komuś wewnętrznie przebaczyć, a równocześnie nie dać mu tego odczuć do momentu zrozumienia przez niego zła własnego czynu. W praktyce jednak oddzielenie tych dwóch działań jest trudne. Natomiast poinformowanie kogoś o przebaczeniu, o które nie prosi; o przebaczeniu odnoszącym się do zła, którego nie zamierza naprawiać, może być dla sprawcy impulsem do odkrycia możliwości życia według praw zupełnie innych niż te, które dotąd regulowały jego postępowanie. Przebaczenie byłoby wówczas czynem podjętym z nadzieja, że okazana miłość jest w stanie zapoczątkować w złym człowieku proces nawrócenia.

Kolejny dylemat związany z przebaczeniem wynika z napięcia, jakie powstaje między przebaczeniem i sprawiedliwością - przebaczenie jawi się bowiem jako działanie, które uniemożliwia dochodzenie sprawiedliwości ${ }^{13}$. W wielu sytuacjach przebaczenie jest faktycznie aktem rezygnacji ze sprawiedliwości, a sprawca zła powinien przecież przynajmniej spróbować naprawić zło, które wyrządził. Oddzielna kwestia dotyczy kary oraz jej znaczenia dla samego sprawcy, który dzięki niej w pewien sposób wyrównuje rachunki ze światem zewnętrznym. Sprawiedliwość może być zatem potrzebna nie tylko osobie skrzywdzonej, ale także samemu sprawcy zła.

Przebaczenie rzutuje ponadto na relacje między sprawcą zła a osobą pokrzywdzoną, w zależności od okoliczności naprawiając je albo utrwalając ich rozkład. Macalester Bell, analizując przebaczenie, wskazuje, że jest to podejmowany ze względu na osobę akt, w którym jej czyn schodzi na drugi plan. Innymi słowy, wybacza się przede wszystkim komuś. Oddaje to praktyka językowa, w której używana jest formuła: „Wybaczam Ci”, bez odniesienia do czynu, którego wybaczenie dotyczy ${ }^{14}$. Przebaczenie może zatem przyczyniać się do naprawienia przez pokrzywdzonego relacji, które zostały zniszczone przez tego, który go skrzywdził. Jeżeli jednak nie zaistnieją odpowiednie okoliczności, czyli świadomość zła u jego sprawcy, przebaczenie może jedynie odsunąć w czasie rozpad relacji i spowodować nawarstwienie zła, przyczyniającego się do jej zniszczenia.

O konsekwencjach przebaczenia można by mówić znacznie więcej, doszukując się ich także w szerszym kontekście społecznym, który rozpoczyna się od najbliższej rodziny, a może dotyczyć zarówno grup społecznych, jak

12 Richards, „Forgiveness”, 82.

13 Murphy, „Forgiveness and mercy”, 699-700.

${ }^{14}$ Bell, „Forgiving”, 361. 
i całych narodów oraz społeczności państwowych ${ }^{15}$. Hannah Arendt docenia wartość przebaczenia w tym wymiarze w następujących słowach: ,przebaczenie służy do zniweczenia uczynków przeszłości, których «grzechy» wiszą jak miecz Damoklesa nad każdym nowym pokoleniem" "16. Jak trudny jest to jednak proces, przekonują badania nad efektami eksperymentu edukacyjnego w Rwandzie, którego celem było uzdrowienie relacji i pojednanie między plemionami Tutsi i Hutu. Pozytywne wyniki, uzyskane zaraz po zakończeniu programu, $\mathrm{w}$ dłuższej perspektywie czasowej zostały znacznie zminimalizowane ${ }^{17}$.

Jeśli przebaczenie ma zostać wpisane w działalność edukacyjną, konieczne jest zatem określenie jego moralnej wartości poprzez wskazanie jego konsekwencji, a następnie odróżnienie przebaczenia mądrego, roztropnego od przebaczenia naiwnego oraz wskazanie zależności między przebaczeniem i sprawiedliwością. $Z$ tych analiz wynikają następujące pytania:

- jaką wartość posiada przebaczenie z punktu widzenia osoby skrzywdzonej?

- w jaki sposób przebaczenie albo jego odmowa wpisują się w osobisty rozwój osoby pokrzywdzonej?

- jaką wartość posiada przebaczenie dla sprawcy zła i jego rozwoju?

- jaka jest zależność między przebaczeniem a sprawiedliwością?

- jaką wartość posiada przebaczenie sprawcy, który nie okazuje skruchy?

- jaką wartość posiadają akty przebaczenia dla rozwoju wspólnot, w ramach których dokonało się zło i które doświadczają jego konsekwencji?

- jak rozpoznawać moralną wartość aktów przebaczenia?

- w jakich okolicznościach przebaczenie posiada moralną wartość, a w jakich jest oznaką pobłażliwości i przejawem naiwności?

Odpowiedzi na te pytania stanowią istotną przesłankę do odpowiedzi na pytanie o sens włączania przebaczenia do teorii pedagogicznej oraz praktyki

15 Zob. na ten temat: Karolina Wigura, Wina narodów. Przebaczenie jako strategia prowadzenia polityki (Gdańsk-Warszawa: Wydawnictwo Naukowe Scholar, 2011); Krzysztof Zięba, „Holocaust i przebaczenie”, w: Ku pamięci, przestrodze i wybaczeniu, red. Danuta Kocurek, Maria Ruman (Kraków: Wydawnictwo «scriptum», 2013), 44-51.

${ }_{16}$ Arendt, Kondycja, 269.

${ }^{17}$ Ervin Staub, Laurie Anne Pearlman, Alexandra Gubin, Athanase Hagengimana, „Healing, Reconciliation, Forgiving and the Prevention of Violence after Genocide or Mass Killing: An Intervention and Its Experimental Evaluation in Rwanda", Journal Of Social And Clinical Psychology 3 (2005): 297-334. 
wychowawczej. Pozytywna odpowiedź na nie umożliwia podjęcie kolejnej kwestii, dotyczącej uwarunkowań i przebiegu procesu przebaczenia, której rozstrzygnięcie stanowi podstawę do określenia, w jaki sposób można wspierać dojrzewanie do przebaczania w ramach procesu wychowania.

\section{Jak przebiega proces przebaczenia?}

Akt przebaczenia określany jest jako trudny. Niekiedy osoba skrzywdzona okazuje się do niego zdolna, a niekiedy przebaczenie zła przekracza jej możliwości. Z tego względu przebaczenia nie da się narzucić. Aby odpowiedzieć na pytanie o możliwość przygotowania/wspierania wychowawczego w dojrzewaniu do przebaczenia, należy najpierw rozpoznać pewne prawidłowości związane z przebaczeniem.

W pierwszym punkcie padło stwierdzenie, że przebaczenie jest wycofaniem negatywnych uczuć, jakie pojawiły się u kogoś w odniesieniu do osoby wyrządzającej mu krzywdę. Choć w tej definicji zawarte jest wskazanie na uczucia, rozwój zdolności do przebaczenia trudno utożsamić z oddziaływaniem na uczucia. Refleksja nad człowiekiem i jego działaniami, a do nich z pewnością należy zaliczyć akt przebaczenia, skłaniają do wniosku, że jest ono dziełem władz umysłowych - rozumu i woli. W praktyce oznaczałoby to, że o przebaczeniu lub jego braku decydują zarówno względy poznawcze, jak i wolicjonalne. Innymi słowy, z jednej strony łatwiej przebaczyć temu, którego sytuację poznawczą i uwarunkowania osobowościowe lepiej rozumiemy, a z drugiej strony o przebaczeniu decyduje nie tyle zrozumienie, co stosunek do sprawcy zła. Stwierdzenia te potwierdzają badania empiryczne. Michael E. McCullough oraz jego współpracownicy wykazali na przykład, że gotowość do wybaczenia sprawcy może być thumaczona percypowaną odpowiedzialnością sprawcy, jakością jego motywacji i stopniem intencjonalności działania ${ }^{18}$, a w bliskich relacjach przebaczenie ułatwia znacząco empatia do partnera wyrządzającego krzywdę ${ }^{19}$. Z kolei zespół badający przemiany społeczne w Irlandii Północnej wykazał, że warunkiem przeba-

${ }_{18}$ Michael E. McCullough, K. Chris Rachal, Steven J. Sandage, Everett L. Worthington jr, Susan Wade Brown, Terry L. Hight, „Interpersonal Forgiving in Close Relationships: II. Theoretical Elaboration and Measurement", Journal of Personality and Social Psychology 75, 5 (1998): 1986.

${ }_{19}$ Michael E. McCullough, Everett L. Worthington, Jr., Kenneth C. Rachal, „Interpersonal Forgiving in Close Relationships”, Journal of Personality and Social Psychology 73, 2 (1997): 322. 
czenia jest kontakt między zwaśnionymi grupami, a w jego ramach dążenie do wspólnych celów i odkrywanie człowieczeństwa postrzeganej dotąd jako wrogiej osoby ${ }^{20}$. Oznaczałoby to, że projekty edukacyjne, które miałyby przygotowywać do przebaczenia, powinny z jednej strony przyczyniać się do lepszego poznania innego człowieka, jego sposobu myślenia oraz działania, jego możliwości oraz ograniczeń, a także słabości ${ }^{21}$, a z drugiej - prowadzić do poprawy jakości relacji międzyludzkich.

Prawidłowości, do których się odwołano, niczego nie rozstrzygają ale wywołują kolejne pytania (rozpoczynając od tych, które już zostały postawione):

- jaka jest zależność między poznaniem sprawcy zła i motywów jego działania a skłonnością do przebaczenia mu?

- jaki jest związek między postawą sprawcy, zmianami w jego sposobie myślenia i zachowaniu a skłonnością do przebaczenia mu?

- jak przebaczenie jest uwarunkowane w poznaniu ludzkiej przygodności (niedoskonałości natury), dotyczącej zarówno sprawcy zła, jak i osoby pokrzywdzonej?

- jak osiagana jest motywacja do przebaczenia?

- jak zdolność do przebaczenia zależy od jakości wspólnot międzyludzkich?

${ }^{20}$ Miles Hewstone, Ed Cairns, Alberto Voci, Juergen Hamberger, Ulrike Niens, „Intergroup Contact, Forgiveness, and Experience of «The Troubles» in Northern Ireland", Journal of Social Issues 62, 1 (2006): 99-120.

${ }^{21}$ Interesujących danych na ten temat mogą dostarczyć wyniki badań Roberta D. Enrighta i kierowanego przez niego zespołu. Wprowadzili oni do programów szkół w Belfaście oraz Milwaukee cykl zajęć na temat przebaczenia. Belfast został wybrany ze względu na konflikt między katolikami i protestantami, natomiast Milwaukee, największe miasto w stanie Wisconsin, ze względu na poziom przestępczości i ubóstwa. W obu miastach poziom agresywnych zachowań wśród dzieci był wyższy niż w grupie kontrolnej - wśród dzieci w mieście Madison. Po przeprowadzeniu cyklu zajęć, trwającego około 12 tygodni, okazało się, że poziom agresji obniżył się, natomiast wzrósł stopień współpracy między uczniami. O programie: Robert D. Enright, Elizabeth A. Gassin, Jeanette A. Knutson, „Waging Peace Through Forgiveness Education in Belfast, Northern Ireland: A Review and Proposal for Mental Health Improvement of Children", Journal of Research in Education 13, 1 (2003): 51-61; Robert D. Enright, Jeanette A. Knutson Enright, Anthony C. Holter, Thomas Baskin, Casey Knutson, „Waging peace through forgiveness in Belfast, Northern Ireland II: Educational programs for mental health improvement of children", Journal of Research in Education 17, 1 (2007): 63-78. Na modelach Roberta D. Enrighta opierano także projekty edukacyjne odnoszące się do innych trudności wymagających rozwiązania: Radhi Al-Mabuk, Robert D. Enright, Paul A. Cardis, „Forgiveness education with parentally love-deprived late adolescents”, Journal of Moral Education 24 (1995): 427-444. 
- w jakich relacjach (o jakich modelach: autotelicznych czy instrumentalnych) łatwiej jest przebaczyć?

- jak wychowywać do przebaczenia, aby było ono aktem rozumnym?

- jak w procesie przebaczania zintegrować emocje z rozumną oceną sytuacji i wyborem najlepszej drogi postępowania?

Mówiąc o przebaczeniu, należy również zwrócić uwagę na to, że jest ono procesem ${ }^{22}$, w którym występują takie etapy jak rozpoznanie doznanej krzywdy, rozpoznanie i przeżycie własnego cierpienia. Ich pominięcie w procesie przebaczania może odbić się negatywnie na osobie skrzywdzonej, dokonującej przebaczenia. Włączenie przebaczenia do refleksji pedagogicznej oraz praktycznej pedagogii domaga się zatem uwzględnienia sugestii, wynikających z odpowiedzi na pytania:

- jak przebiega proces przebaczania?

- przeżycie jakich etapów własnego cierpienia jest niezbędne w procesie przebaczania?

- jak uczyć się cierpliwości w przeżywaniu cierpienia i procesie przebaczania?

Ostatnim problemem, któremu należy się przyjrzeć, rozważając przebaczenie w kontekście pedagogicznym, jest wpływ religii na przebieg tego procesu. Dla wielu osób religia wyznacza ważną perspektywę w ocenie życiowych doświadczeń, wpływając też na stosunek do doświadczonego zła ${ }^{23}$.

\section{Jak religia wpływa na proces przebaczenia?}

Religijna narracja na temat przebaczenia kształtuje niewątpliwie stosunek wielu osób do doświadczonego zła ze względu na zaangażowanie autorytetu Boga do interpretacji doświadczanej rzeczywistości ${ }^{24}$. Jak zatem odnieść się w wychowaniu do przebaczenia do religijnych uwarunkowań ludzkiego życia i działania?

Pierwszy problem dotyczy przesłania poszczególnych religii odnośnie do przebaczenia. Donald H. Bishop po przeanalizowaniu podstawowych tekstów kilku najbardziej popularnych religii świata stwierdził, że przesłanie

${ }^{22}$ Annalisa Giulianini, O przebaczeniu, czyli jak uleczyć duszę, thum. Magdalena Osocha (Kraków: Wydawnictwo Franciszkanów „Bratni Zew”, 2008), 44-52.

${ }^{23}$ Mark S. Rye, Kenneth I. Pargament, M. Amir Ali, Guy L. Beck, Elliot N. Dorff, Charles Hallisey, Vasudha Narayanan, James G. Williams, „Religious Perspectives on Forgiveness", w: Forgiveness. Theory, Research, and Practice, red. Michael E. McCullough, Kenneth I. Pargament, Carl E. Thoresen (New York-London: The Guilford Press, 2000), 17-40.

${ }^{24}$ Giulianini, O przebaczeniu, 83-98, 135-141. 
analogiczne do chrześcijańskiego, w którym pojawia się wymaganie przebaczenia bezwarunkowego i na dodatek odnoszącego się także do wrogów, można znaleźć także w buddyzmie i hinduizmie. W systemach takich jak konfucjanizm, islam czy judaizm przebaczenie wymagane jest z kolei jedynie w sytuacji wzajemności. Dla nich kluczowym pojęciem jest sprawiedliwość. Wskazane różnice dają się, jego zdaniem, wytłumaczyć, ponieważ konfucjanizm, islam i judaizm rozwijały się w ramach określonego modelu społeczno-politycznego, który wspierały. Z kolei w chrześcijaństwo, buddyzm i hinduizm nie zostało wpisane tworzenie struktur społeczno-politycznych, stąd podstawową w nich wartością stała się miłość, a w konsekwencji dowartościowano przebaczenie. We wspomnianych systemach przebaczenie jest jednak różnie uzasadniane: w buddyzmie - psychologicznie, w hinduizmie - metafizycznie, w chrześcijaństwie - teologicznie ${ }^{25}$.

Drugi problem dotyczy sposobu odczytywania przesłania dotyczącego przebaczenia. Z jednej strony słowa wydają się zrozumiałe. Jak czytamy w cytowanej już Ewangelii według św. Mateusza: „Jeśli bowiem przebaczycie ludziom ich przewinienia, i wam przebaczy Ojciec wasz niebieski. Lecz jeśli nie przebaczycie ludziom, i Ojciec wasz nie przebaczy wam waszych przewinien” $(6,14-15)$. I dalej: „Wtedy Piotr (...) zapytał: «Panie, ile razy mam przebaczyć, jeśli mój brat wykroczy przeciwko mnie? Czy aż siedem razy?» Jezus mu odrzekł: «Nie mówię ci, że aż siedem razy, lecz aż siedemdziesiąt siedem razy»" (18, 21-22). Z drugiej jednak strony w kontekście odczytanych literalnie słów ofiara może okazać się osobą skrzywdzoną podwójnie. Najpierw została bowiem skrzywdzona przez tego, kto wyrządził jej zło, a następnie została odrzucona przez Boga, ponieważ przebaczenie przerosło jej możliwości. Zderzenie wymagań, jakie stawiane są w religii, $\mathrm{z}$ własnymi ograniczeniami $\mathrm{w}$ zakresie przebaczenia doznanego zła może prowadzić do poważnych dylematów. Anselm Grün, mnich benedyktyński, a równocześnie doświadczony terapeuta, odwołując się do własnej praktyki, stwierdza:

Jedni noszą w sobie ślady surowego wychowania: mówiono im, że powinni każdemu przebaczyć, a tymczasem oni czują, że nie mogą się na to zdobyć - że dawno zadana rana ciągle jeszcze sprawia ból. Niektórzy nakaz przebaczania pojmują w tym sensie, że powinni stłumić w sobie uczucie złości i gniewu przeciwko tym, którzy ich skrzywdzili, i że nie pozostaje im nic innego, jak tylko

${ }_{25}$ Donald H. Bishop, „Forgiveness in Religious Thought”, Studies in Comparative Religion 2, 1 (1968): 21-30. 
ludziom tym jak najszybciej przebaczyć. To wszakże przekracza ich siły, stale jeszcze bowiem odczuwają gniew i urazę. Czują, że te uczucia ich paraliżują ${ }^{26}$.

Zestawiając przytoczone sformułowania, nietrudno zbudować sobie obraz Boga budzący w człowieku lęk - obraz Boga, którego trudno zrozumieć i najlepiej unikać.

Równocześnie jednak wymaganie przebaczenia jest w pewnym sensie zrozumiałe, jeżeli stan eschatologicznego szczęścia - szczęścia człowieka oraz szczęścia Boga - jest uwarunkowany nie tylko pojednaniem człowieka z Bogiem, poprzedzonym przebaczeniem udzielonym człowiekowi przez Boga, ale także przebaczeniem i pojednaniem między ludźmi. Analogię stanu niepełnego szczęścia odnajdujemy w Ewangelii według św. Łukasza, w opowiadaniu o synu marnotrawnym. $Z$ jednej strony ojciec odczuwa radość z powrotu młodszego syna, którego widok sprawia, że wybacza mu krzywdę wyrządzoną jego odejściem, a z drugiej trudno mówić o pełnym szczęściu, gdy starszy syn, będący cały czas z ojcem, teraz nie chce przestąpić progu domu ojca (por. Łk 15, 11-31). Czy w domu, w którym bracia ze sobą nie rozmawiają, może panować szczęście? Co więcej, czy człowiek może być szczęśliwy w obecności Boga, jeżeli jego brata tam nie ma? Wacław Hryniewicz, pisząc o niebie, stwierdza: „Kiedyś przed obliczem Boga wszyscy dokonamy ostatecznej weryfikacji. Zdumienie otworzy nam oczy i serca. Tam nauczymy się prawdziwie przebaczać i cieszyć się szczęściem wszystkich"27. Jak zatem interpretować biblijną narrację na temat przebaczenia?

Z przedstawionych analiz wynikają zatem kolejne kwestie, które domagają się rozstrzygnięcia w ramach pedagogicznej refleksji nad przebaczeniem:

- jakie normy w odniesieniu do przebaczenia pojawiają się w poszczególnych religiach?

- która z postaw: sprawiedliwość czy przebaczenie, w nich dominuje?

- jak religia uzasadnia wymóg przebaczenia?

- jak religia ocenia brak przebaczenia?

- jakie sankcje związane są z brakiem przebaczenia?

- dlaczego człowiek wierzący przebacza: z lęku czy z miłości?

- jak w religii wychowywać do przebaczenia, aby nie wprowadzać w sytuację lęku przed Bogiem?

${ }^{26}$ Grün, Przebacz, 7.

27 Wacław Hryniewicz, Wiara rodzi się $w$ dialogu (Kraków: Wydawnictwo WAM, 2015), 81 . 
Warto postawić jeszcze jedno pytanie, choć odpowiedź na nie wymaga wkroczenia już w dziedzinę teologii: jakie są granice przebaczenia czysto naturalnego, innymi słowy, czy człowiek jest w stanie w pełni wybaczyć, wykorzystując swój naturalny potencjał, czy - wręcz przeciwnie - pełne wybaczenie jest możliwe przy wsparciu łaski?

$* * *$

Pytań, które pojawiają się w ramach analizowania kwestii przebaczenia w kontekście pedagogicznym, można by postawić z pewnością znacznie więcej, odnosząc się chociażby do doświadczeń w zakresie wychowania do przebaczenia czy do otwartości poszczególnych pedagogii na problem wychowania do przebaczenia. Celem tego tekstu nie było jednak wyliczenie wszystkich możliwych pytań, ale nakreślenie złożoności problematyki miejsca przebaczenia w wychowaniu oraz wychowania do przebaczenia. Wprowadzenie kwestii przebaczenia do procesów edukacyjnych bez uprzedniej refleksji na wskazane tematy byłoby z pewnością nie tylko naiwne, ale w odniesieniu do niektórych wychowanków, szczególnie tych niosących bagaż trudnych życiowych doświadczeń, mogłoby prowadzić do kolejnych rozterek, dylematów i kryzysów życiowych.

\section{Educational Questions of Forgiveness (Summary)}

Harm and answer to it in a form of forgiveness or refusal of forgiveness constitute important elements of human life, thus, of human development; therefore, they should become the subjects of educational reflection. However, the issues of relations between forgiveness and human development cannot be decided on with unequivocal statements. Despite the positive perception of forgiveness, one could easily see that forgiveness for which the victim is not mature enough yet may destroy him, and forgiving the wrongdoer, who does not understand his acts, may confirm his belief of rightness of his wrong deeds. In this context, when discussing the role of forgiveness in education, and, consequently, education of forgiveness, one should ask the question of the essence of forgiveness, of its moral value and, especially, relation to justice, of its conditions and course and; finally, its religious dimension. This article is of introductory nature - it aims at introducing problems and asking question, and not at solving and answering them. Implementation of the issue of forgiveness to the educational processes without prior reflection on the mentioned sub- 
jects would be not only naive but also, in relation to some pupils and especially those burdened with difficult experiences, may lead to further dilemmas and life crises.

Key words: harm; forgiveness; moral aspect of forgiveness; conditions of forgiveness; religion and forgiveness.

\section{Pedagogiczne pytania o przebaczenie (Streszczenie)}

Krzywda oraz odpowiedź na nią w postaci przebaczenia lub jego odmowy stanowią istotne elementy ludzkiego życia, przez co wpisują się w rozwój człowieka i jako takie powinny stać się przedmiotem refleksji pedagogicznej. Kwestii zależności między przebaczeniem a ludzkim rozwojem nie da się jednak rozstrzygnąć jednoznacznymi stwierdzeniami. Mimo że przebaczenie postrzegane jest jako akt pozytywny, nie sposób nie zauważyć, że przebaczenie, do którego pokrzywdzony wewnętrznie nie dojrzał, może niszczyć jego samego, a akt przebaczenia sprawcy zła, który nie rozumie tego, co czyni, może utwierdzać go w słuszności złego postępowania. W tym kontekście, myśląc o roli przebaczenia w wychowaniu, a w konsekwencji także o wychowaniu do przebaczenia, należy zadać pytania o istotę przebaczenia, o jego moralną wartość, a zwłaszcza stosunek do sprawiedliwości, o jego uwarunkowania i przebieg, wreszcie o jego wymiar religijny. Niniejszy tekst ma charakter wprowadzający do tematu - jego celem jest nakreślenie problemów, postawienie pytań, a nie ich rozwiązywanie. Wprowadzenie kwestii przebaczenia do procesów edukacyjnych bez uprzedniej refleksji na wskazane tematy byłoby z pewnością nie tylko naiwne, ale w odniesieniu do niektórych wychowanków, szczególnie tych niosących bagaż trudnych życiowych doświadczeń, mogłoby prowadzić do kolejnych rozterek, dylematów i kryzysów życiowych.

Słowa kluczowe: krzywda; przebaczenie; moralny aspekt przebaczenia; uwarunkowania przebaczenia; religia a przebaczenie.

\section{Bibliografia}

Al-Mabuk, Radhi, Robert D. Enright, Paul A. Cardis. „Forgiveness Education with Parentally Love-Deprived Late Adolescents". Journal of Moral Education 24 (1995): 427-444.

Arendt, Hannah. Kondycja ludzka, tłum. Anna Łagodzka. Warszawa: Wydawnictwo Aletheia, 2010. 
Augsburger, David. Sztuka przebaczania, tłum. Andrzej Czarnocki. Warszawa: Świat Książki, 1996.

Augustyn, Józef. Ból krzywdy, radość przebaczenia. Kraków: Wydawnictwo M, 1998.

Bassett, Rodney L., Kelly M. Bassett, Matthew W. Lloyd, Jason L. Johnson. „Seeking Forgiveness: Considering The Role Of Moral Emotions". Journal of Psychology and Theology 34, 2 (2006): 111-124.

Bell, Macalester. „Forgiving Someone for Who They Are (and Not Just What They've Done)". Philosophy and Phenomenological Research 3 (2008): 625-658.

Bishop, Donald H. „Forgiveness in Religious Thought”. Studies in Comparative Religion 2, 1 (1968): 21-30.

Enright, Robert D., Elizabeth A. Gassin, Jeanette A. Knutson. „Waging Peace Through Forgiveness Education in Belfast, Northern Ireland: A Review and Proposal for Mental Health Improvement of Children". Journal of Research in Education 13, 1 (2003): 51-61.

Enright, Robert D., Jeanette A. Knutson Enright, Anthony C. Holter, Thomas Baskin, Casey Knutson. „Waging Peace through Forgiveness in Belfast, Northern Ireland II: Educational Programs for Mental Health Improvement of Children". Journal of Research in Education 17, 1 (2007): 63-78.

Giulianini, Annalisa. O przebaczeniu, czyli jak uleczyć duszę, thum. Magdalena Osocha. Kraków: Wydawnictwo Franciszkanów „Bratni Zew”, 2008.

Grün, Anselm. Przebacz samemu sobie. Pojednanie - przebaczenie, thum. Juliusz Zychowicz. Kraków: Wydawnictwo WAM, 2001.

Harris, Alex H. S., Frederic Luskin, Sonya B. Norman, Sam Standard, Jennifer Bruning, Stephanie Evans, and Carl E. Thoresen. „Effects of a Group Forgiveness Intervention on Forgiveness, Perceived Stress, and Trait-Anger". Journal of Clinical Psychology 6 (2006): 715-733.

Hewstone, Miles, Ed Cairns, Alberto Voci, Juergen Hamberger, Ulrike Niens. „Intergroup Contact, Forgiveness, and Experience of «The Troubles» in Northern Ireland". Journal of Social Issues 62, 1 (2006): 99-120.

Hryniewicz, Wacław. Wiara rodzi się $w$ dialogu. Kraków: Wydawnictwo WAM, 2015.

Hughes, Paul M. „Forgiveness”. W: The Stanford Encyclopedia of Philosophy, red. Edward N. Zalta (Spring 2015 Edition). http://plato.stanford.edu/archives/ spr2015/entries/forgiveness/ (dostęp: 19.05.2016)

Król, Aldona. „Wychowanie do przebaczenia”. W: Wychowanie chrześcijańskie. Między tradycja a wspótczesnościa, red. Alina Rynio, 432-442. Lublin: Wydawnictwo KUL, 2007.

Larsen, Ernie. Od gniewu do przebaczenia. Jak przezwyciężyć toksyczne emocje, by żyć w zgodzie ze sobq, thum. Ewa Zaremba. Gdańsk: GWP, 2000. 
McCullough, Michael E., Everett L. Worthington jr, Kenneth C. Rachal. „Interpersonal Forgiving in Close Relationships". Journal of Personality and Social Psychology 73, 2 (1997): 321-336.

McCullough, Michael E., K. Chris Rachal, Steven J. Sandage, Everett L. Worthington, Jr., Susan Wade Brown, Terry L. Hight. „Interpersonal Forgiving in Close Relationships: II. Theoretical Elaboration and Measurement”. Journal of Personality and Social Psychology 75, 5 (1998): 1986-1603.

Mróz, Mirosław. Tajemnica ludzkiej nieprawości. Aktualność nauki św. Tomasz z Akwinu o złu moralnym i wadach głównych. Toruń: Wydawnictwo Naukowe UMK, 2010.

Murphy, Jeffrie G. „Forgiveness and Mercy”. W: Routledge Encyclopedia of Philosophy, t. 3, red. Edward Craig, 697-701. London-New York, Routledge, 1998.

Murphy, Jeffrie G. „Forgiveness and Resentment”, Midwest Studies in Philosophy 7, 1 (1982): 503-516. DOI: 10.1111/j.1475-4975.1982.tb00106.x.

Newberry, Paul A. „Joseph Butler on Forgiveness: A Presupposed Theory of Emotion". Journal of the History of Ideas 62, 2 (2001): 233-244. DOI: dx.doi. org/10.1353/jhi.2001.0016.

Richards, Norvin. „Forgiveness”. Ethics 99, 1 (1988): 77-97.

Rye, Mark S., Kenneth I. Pargament, M. Amir Ali, Guy L. Beck, Elliot N. Dorff, Charles Hallisey, Vasudha Narayanan, James G. Williams. „Religious Perspectives on Forgiveness". W: Forgiveness. Theory, Research, and Practice, red. Michael E. McCullough, Kenneth I. Pargament, Carl E. Thoresen, 17-40. New York-London: The Guilford Press, 2000.

Rye, Mark S., Kenneth I. Pargament. „Forgiveness and Romantic Relationship in College. Can It Heal the Wounded Heart?'. Journal of Clinical Psychology 4 (2002): 419-441.

Scheler, Max. Resentyment a moralność, tłum. Jan Garewicz. Warszawa: Czytelnik, 1997.

Staub, Ervin, Laurie Anne Pearlman, Alexandra Gubin, Athanase Hagengimana. „Healing, Reconciliation, Forgiving and the Prevention of Violence after Genocide or Mass Killing: An Intervention and Its Experimental Evaluation in Rwanda". Journal of Social and Clinical Psychology 3 (2005): 297-334.

Szymala, Katarzyna. „Przebaczenie jako działanie. O znaczeniu tego, co nieprzewidywalne dla edukacji”. Parezja 1 (2015): 103-116. DOI: 10.15290/parezja.2015.03.09.

West, William. „Issues Relating to the Use of Forgiveness in Counselling and Psychotherapy". British Journal of Guidance \& Counselling 4 (2001): 415-423.

Wigura, Karolina. Wina narodów. Przebaczenie jako strategia prowadzenia polityki. Gdańsk-Warszawa: Wydawnictwo Naukowe Scholar, 2011. 
Wrońska, Katarzyna. „Przebaczenie jako problem wychowania”. W: Pedagogika kultury - wychowanie do wyboru wartości, red. Bogusław Żurakowski, 57-78. Kraków: Oficyna wydawnicza „Impuls”, 2003.

Zięba, Krzysztof. „Holocaust i przebaczenie”. W: Ku pamięci, przestrodze i wybaczeniu, red. Danuta Kocurek, Maria Ruman, 29-52. Kraków: Wydawnictwo «scriptum», 2013. 